\title{
Shikinefragalides A-D, new tricyclic macrolides produced by Stachybotryaceae sp. FKI-9632
}

\author{
Rima Koike ${ }^{1}$ Yoshihiro Watanabe $\mathbb{D}^{1,2} \cdot$ Kazuho Kato $^{3} \cdot$ Yudai Mikasa $^{3} \cdot$ Kota Shimizu $^{3} \cdot$ Kenichi Nonaka $^{1,2}$. \\ Masako Honsho $^{2} \cdot$ Takuya Suga $^{1,2} \cdot$ Rei Hokari $^{1,2} \cdot$ Aki Ishiyama $^{1,2} \cdot$ Yukihiro Asami $\mathbb{D}^{1,2} \cdot$ Masato Iwatsuki $\mathbb{D}^{1,2}$
}

Received: 11 January 2022 / Revised: 7 February 2022 / Accepted: 9 February 2022 / Published online: 4 March 2022

(c) The Author(s), under exclusive licence to the Japan Antibiotics Research Association 2022

\begin{abstract}
Four new tricyclic macrolides, named shikinefragalides A (1), B (2), C (3) and D (4), were isolated by physicochemical (PC) screening from a static culture material of Stachybotryaceae sp. FKI-9632. Their structures were elucidated as new analogs of colletofragarones by MS and NMR analyses. Compounds $\mathbf{1}$ and $\mathbf{2}$ showed weak antimalarial activity and cytotoxicity.
\end{abstract}

\section{Introduction}

Numerous novel natural products have been discovered from fungal species. Some of them were developed as human medicines (e.g., penicillins, cephalosporins, statins and candins), animal drugs (e.g., penicillins and cephalosporins), and agrochemicals (e.g., afidopyropene) [1, 2]. Recent advances in whole-genome sequencing technology have revealed that the fungi have many biosynthetic gene clusters encoding unidentified secondary metabolites that surpass the number of metabolites identified so far [3, 4]. Thus, fungi are now re-recognized as one of the most important microorganisms as potential sources for new drugs and agrochemicals.

Physicochemical (PC) screening is a methodology to discover new natural compounds guided by physicochemical

These authors contributed equally: Rima Koike, Yoshihiro Watanabe

Supplementary information The online version contains supplementary material available at https://doi.org/10.1038/s41429022-00512-y.

Masato Iwatsuki

iwatuki@lisci.kitasato-u.ac.jp

1 Graduate School of Infection Control Sciences, Kitasato University, 5-9-1 Shirokane, Minato-ku, Tokyo, 108-8641 Tokyo, Japan

2 Ōmura Satoshi Memorial Institute, Kitasato University, 5-9-1 Shirokane, Minato-ku, Tokyo, 108-8641 Tokyo, Japan

3 School of Science, Kitasato University, 1-15-1, Kitazato, Minamiku, Sagamihara, Kanagawa 252-0373, Japan properties including molecular weight, molecular formula, UV profile and so on. Our research group has been searching for new fungal compounds by PC screening and discovered new fungal metabolites such as hatsusamides A and B [5] from Penicillium steckii FKJ-0213, pochoniolides A and B [6] from Pochonia chlamydosporia var. spinulospora FKI-7537, cipralphelin [7] from Penicillium brevicompactum FKJ-0123 and so on so far. After their initial discovery, many of them were found to exhibit useful biological activities.

During our recent PC screening on culture broths of 25 fungal strains by LC-DAD-ESI-MS analysis combined with dereplication by natural product database "Dictionary of Natural Products" [8], we selected a Stachybotryaceae sp. FKI-9632 strain as a producer of presumed new compounds. As a result of purification guided by LC-DAD-ESIMS analysis, four new fungal tricyclic macrolides, named shikinefragalides A (1)-D (4), were isolated from a static culture of Stachybotryaceae sp. FKI-9632 (Fig. 1). In this paper, we report the isolation, structure elucidation, and biological activity of 1-4.

\section{Materials \& methods}

\section{General experiments}

The purification of 1-4 by an ODS column was conducted using YMC-gel ODS-A (150 $\mu \mathrm{m}$, YMC Co., Kyoto, Japan). Preparative HPLC was performed using a Capcell pak $\mathrm{C}_{18}$ MG-II column (20 i.d. $\times 250 \mathrm{~mm}$, Osaka Soda Co. Ltd., Osaka, Japan). LC-DAD-ESI-MS spectra were obtained 
Fig. 1 Structures of shikinefragalides A (1)-D (4)
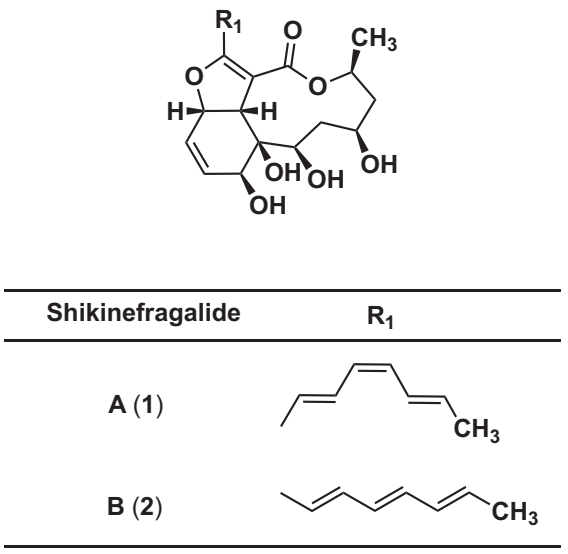
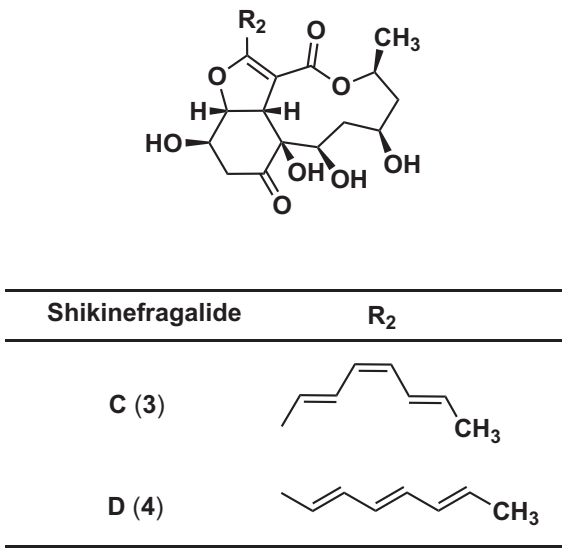

using an AB Sciex Triple TOF ${ }^{\mathrm{TM}} 5600^{+}$LC-MS/MS Systems (AB Sciex, Framingham, MA, USA). NMR spectra were obtained using a Varian XL-400 spectrometer (Agilent Technologies, CA, USA) or a JEOL JNM-ECA-500 (JEOL, Tokyo, Japan), with ${ }^{1} \mathrm{H}$ NMR at 400 or $500 \mathrm{MHz}$ and ${ }^{13} \mathrm{C}$ $\mathrm{NMR}$ at 100 or $125 \mathrm{MHz}$ in DMSO- $d_{6}$ or $\mathrm{CD}_{3} \mathrm{OD}$. The chemical shifts are expressed in ppm and are referred to DMSO- $d_{6}(2.48 \mathrm{ppm})$ or $\mathrm{CD}_{3} \mathrm{OD}(3.31 \mathrm{ppm})$ in the ${ }^{1} \mathrm{H}$ NMR spectra and to DMSO- $d_{6}$ (39.5 ppm) or $\mathrm{CD}_{3} \mathrm{OD}(49.0$ $\mathrm{ppm}$ ) in the ${ }^{13} \mathrm{C}$ NMR spectra. IR spectra (ATR) were taken on a FT-210 Fourier transform infrared spectrometer (Horiba Ltd., Kyoto, Japan). UV spectra were acquired with a Hitachi U-2800 spectrophotometer (Hitachi Ltd., Tokyo, Japan). Optical rotation was measured with a JASCO P-2200 polarimeter (JASCO Co., Tokyo, Japan). CD spectra were recorded with a J-720 circular dichroism spectrometer (JASCO).

\section{Taxonomic studies of strain FKI-9632}

Soil samples around the root of plants were collected from Shikine Island, Izu Islands, Tokyo, Japan in 2018. The soil samples were diluted with Winogradsky's solution and spread on Czapek yeast extract agar (CYA) for cultivation. For isolating fungal species, that CYA was used with 50 $\mathrm{mg}^{-1}$ rose bengal, $100 \mathrm{mg}^{-1}$ chloramphenicol and 100 $\mathrm{mg} \mathrm{l}^{-1}$ kanamycin and kept at $25^{\circ} \mathrm{C}$ for 7 days.

DNA extraction, polymerase chain reaction (PCR) amplification of the ITS region and sequencing of the strain FKI-9632 were conducted. PCR amplification products were fabricated using the QIAGEN $^{\bullet}$ Fast Cycling PCR Kit (Qiagen Inc., Valencia, CA, USA). Sequencing products were purified using BigDye XTerminator Purification Kit (Applied Biosystems, Foster City, CA, USA), and samples were analyzed on an ABI PRISM 3130 Genetic Analyzer (Applied Biosystems). Contigs were assembled using the forward and reverse sequences with the SeqMan Pro program from the Lasergene 10 package (DNASTAR Inc., Madison, WI, USA).

\section{Fermentation}

Strain FKI-9632 was grown and maintained on an agar slant consisting of $0.1 \%$ glycerol, $0.08 \% \mathrm{KH}_{2} \mathrm{PO}_{4}, 0.02 \% \mathrm{~K}_{2} \mathrm{HPO}_{4}$, $0.02 \% \mathrm{MgSO}_{4} \cdot 7 \mathrm{H}_{2} \mathrm{O}, 0.02 \% \mathrm{KCl}, 0.2 \% \mathrm{NaNO}_{3}, 0.02 \%$ yeast extract and $1.5 \%$ agar (adjusted to $\mathrm{pH} 6.0$ before sterilization). A loopful of spores of the strain was inoculated into $100 \mathrm{ml}$ of the GP seed medium consisting of $2.0 \%$ glucose, $0.5 \%$ Hipolypepton (Nihon Pharmaceutical Co., Tokyo, Japan), $0.2 \%$ yeast extract, $0.1 \% \mathrm{KH}_{2} \mathrm{PO}_{4}, 0.05 \% \mathrm{MgSO}_{4} \cdot 7 \mathrm{H}_{2} \mathrm{O}$, and $0.1 \%$ agar (adjusted to $\mathrm{pH} 6.0$ before sterilization) in a 500-ml Erlenmeyer flask. The flask was incubated on a rotary shaker (210 rpm) at $27^{\circ} \mathrm{C}$ for 3 days. Fifty milliliters of the seed cultures were inoculated into each of two culture bags (Ulpack 47, Hokken Co. Ltd., Tochigi, Japan) containing a production medium ( $1 \mathrm{~kg}$ of water-sodden rice and $10 \mathrm{~g}$ of seaweed tea powder (Ito en Ltd., Tokyo, Japan)). Static fermentation was continued at $25^{\circ} \mathrm{C}$ for 15 days.

\section{Antimicrobial activity}

The following microorganisms were used for evaluation of antimicrobial activity on a paper disc method: Bacillus subtilis KB 211 (ATCC 6633), Kocuria rhizophila KB 212 (ATCC 9341), Escherichia coli KB 213 (NIHJ), Xanthomonas oryzae KB 88, Candida albicans KF 1 (ATCC 64548) and Mucor racemosus KF 223 (IFO 4581). All compounds were prepared as $1 \mathrm{mg} \mathrm{ml}^{-1} \mathrm{MeOH}$ solution. Each paper disk (diameter $6 \mathrm{~mm}$, thin type, Advantec, Tokyo, Japan) impregnated with $10,3,1,0.3,0.1$ and $0.03 \mu \mathrm{g}$ of $\mathbf{1 - 4}$ was put into an agar plate, followed by incubation for $1-2$ days at $37^{\circ} \mathrm{C}$ for $B$. subtilis, K. rhizophila and E. coli $\mathrm{KB} 213$ (NIHJ) or $27^{\circ} \mathrm{C}$ for $X$. oryzae, $C$. albicans and $M$. racemosus.

\section{In vitro cultivation of Plasmodium falciparum and antimalarial assay}

In vitro cultivation and in vitro antimalarial activities against $P$. falciparum FCR3 (chloroquine-sensitive) and K1 (chloroquine- 
resistant) strains were evaluated, using the method described previously [9]. This study was approved by the "Kitasato Institute Hospital Research Ethics Committee (No12102)", because of the donation of human erythrocytes from volunteers.

\section{Cytotoxic assay against MRC-5 cells}

Cytotoxic assay against human fetal lung fibroblast MRC-5 cells was carried out as described previously [10].

\section{Results}

\section{Identification of a fungal FKI-9632 strain as a producer of 1-4 by PC screening}

PC screening was performed as shown in Scheme $\mathrm{S} 1$. In this PC screening, we used 25 fungal strains that were presumed to be unknown species with homology of less than $90 \%$ compared to known species from the genetic analysis. They were selected from 600 fungal strains of FKI-9401 10000. These 25 strains were cultured on two different media to get 50 cultured broths. The obtained cultured broths were analyzed by LC-DAD-ESI-MS analysis to collect data sets of molecular weights and UV spectra. Manual dereplication by natural product database "Dictionary of Natural Products" [8], on DVD (Ver. 26.2, CRC Press) using these data sets allowed us to find 4 strains as producers of presumed new compounds (Table S1). As a result of re-culturing these strains, reproducibility was obtained only for FKI-9632 strain which produce a presumed new compound detected as a $[\mathrm{M}+\mathrm{H}]^{+}$ion $(\mathrm{m} / \mathrm{z}$ 405.1907) and a characteristic UV profile $\left(\lambda_{\max } 264\right.$ and $337 \mathrm{~nm}$ ) by LC-DAD-ESI-MS analysis (Fig. S1).

\section{Taxonomy of the producing strain of Stachybotryaceae sp. FKI-9632}

The fungal strain FKI-9632 was isolated from a soil sample around Smilax china in Shikine Island, Izu Islands, Tokyo, Japan. This strain produced verticillium-like conidiophores (Fig. S2). The internal transcribed spacer (ITS) region including $5.8 \mathrm{~S}$ ribosomal RNA gene sequence of FKI-9632 was compared to sequences in the GenBank database by BLASTN 2.12.0 analysis [11]. The sequence of it was $87.4 \%$ similar to the sequence of CBS 143444 (holotype of Sirastachys cyperacearum Crous \& T.I. Burgess [12], GenBank accession number MH107917). Conidiophores of FKI-9632 were different from characteristics of genus Sirastachys. The producing strain FKI-9632 was identified with the Stachybotryaceae based on sequence analysis.

\section{Isolation of shikinefragalides A-D}

Shikinefragalides A-D were isolated from a 15-day-old static cultured material guided UV and MS profiles using LC-DAD-ESI-MS analysis (Scheme 1). They were purified under light-shielded condition within 3 days after preparation of a cultured material due to light-sensitivity. The stationary culture $(2.0 \mathrm{~kg})$ was extracted with 2.01 of $\mathrm{MeOH}$. After filtration in vacuo, the filtrate was evaporated
Scheme 1 Fermentation and isolation of shikinefragalides A (1)-D (4)

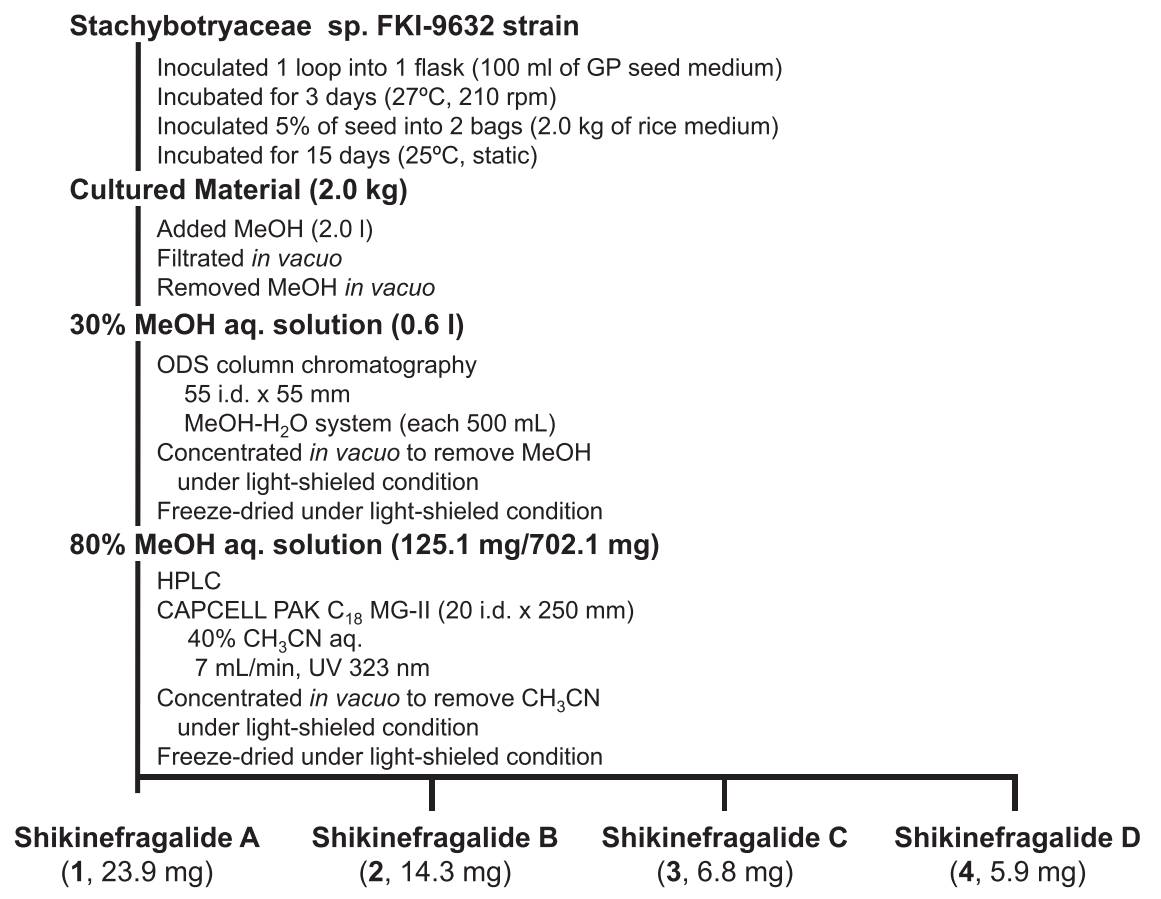


Table $1{ }^{1} \mathrm{H}$ and ${ }^{13} \mathrm{C}$ NMR data of 1 and 2 measured in DMSO- $d_{6}$

\begin{tabular}{|c|c|c|c|c|}
\hline \multirow[b]{2}{*}{ position } & \multicolumn{2}{|c|}{ Shikinefragalide A (1) } & \multicolumn{2}{|c|}{ Sihikinefragalide B (2) } \\
\hline & $\delta_{C}$ & $\delta_{\mathrm{H}}$ (int., mult., $J$ in $\mathrm{Hz}$ ) & $\delta_{\mathrm{C}}$ & $\delta_{\mathrm{H}}$ (int., mult., $J$ in $\mathrm{Hz}$ ) \\
\hline 1 & 77.6 & $5.15(1 \mathrm{H}, \mathrm{dd}, 10.1,3.5)$ & 77.5 & $5.13(1 \mathrm{H}, \mathrm{dd}, 10.0,3.6)$ \\
\hline 2 & 124.4 & $5.66(1 \mathrm{H}, \mathrm{dd}, 9,9,3.5)$ & 124.4 & $5.62(1 \mathrm{H}, \mathrm{dd}, 10.0,3.6)$ \\
\hline 3 & 130.4 & $5.89(1 \mathrm{H}, \mathrm{dd}, 9.9,5.6)$ & 130.3 & $5.87(1 \mathrm{H}, \mathrm{dd}, 10.0,5.6)$ \\
\hline 4 & 64.5 & $4.01(1 \mathrm{H}, \mathrm{dd}, 5.6,5.4)$ & 64.5 & $4.00(1 \mathrm{H}, \mathrm{dd}, 5.6,5.4)$ \\
\hline $4-\mathrm{OH}$ & & $4.39(1 \mathrm{H}, \mathrm{d}, 5.4)$ & & $4.37(1 \mathrm{H}, \mathrm{d}, 5.4)$ \\
\hline 5 & 75.4 & - & 75.4 & - \\
\hline $5-\mathrm{OH}$ & & $4.12(1 \mathrm{H}, \mathrm{s})$ & & $4.10(1 \mathrm{H}, \mathrm{s})$ \\
\hline 6 & 70.6 & $3.37(1 \mathrm{H}, \mathrm{dd}, 9.5,7.1)$ & 70.6 & $3.37(1 \mathrm{H}, \mathrm{dd}, 9.5,7.2)$ \\
\hline $6-\mathrm{OH}$ & & $4.09(1 \mathrm{H}, \mathrm{d}, 7.1)$ & & $4.08(1 \mathrm{H}, \mathrm{d}, 7.2)$ \\
\hline $7 \alpha$ & 41.7 & $1.39(1 \mathrm{H}, \mathrm{dd}, 13.8,9.5)$ & 41.8 & $1.38(1 \mathrm{H}, \mathrm{dd}, 13.9,9.5)$ \\
\hline $7 \beta$ & & $2.06(1 \mathrm{H}, \mathrm{dd}, 13.9,9.3)$ & & $2.05(1 \mathrm{H}, \mathrm{dd}, 13.9,9.5)$ \\
\hline 8 & 68.5 & $3.74(1 \mathrm{H}, \mathrm{m})$ & 68.5 & $3.76(1 \mathrm{H}, \mathrm{m})$ \\
\hline $8-\mathrm{OH}$ & & $4.46(1 \mathrm{H}, \mathrm{d}, 4.2)$ & & $4.45(1 \mathrm{H}, \mathrm{d}, 4.2)$ \\
\hline $9 \alpha$ & 45.3 & $1.90(1 \mathrm{H}$, br. d, 14.5$)$ & 45.3 & $1.89(1 \mathrm{H}$, br. dd, $13.9,1.8)$ \\
\hline $9 \beta$ & & $1.61(1 \mathrm{H}, \mathrm{ddd}, 14.5,11.1,10.0)$ & & $1.61(1 \mathrm{H}, \mathrm{ddd}, 13.9,10.0,9.5)$ \\
\hline 10 & 69.9 & $4.54(1 \mathrm{H}, \mathrm{dqd}, 11.1,6.1,1.9)$ & 69.8 & $4.53(1 \mathrm{H}, \mathrm{dqd}, 10.0,6.2,1.8)$ \\
\hline 11 & 165.1 & - & 165.2 & - \\
\hline 12 & 108.4 & - & 107.8 & - \\
\hline 13 & 157.8 & - & 158.0 & - \\
\hline 14 & 46.6 & $3.63(1 \mathrm{H}, \mathrm{d}, 10.1)$ & 46.6 & $3.61(1 \mathrm{H}, \mathrm{d}, 10.0)$ \\
\hline 15 & 21.5 & $1.29(3 \mathrm{H}, \mathrm{d}, 6.1)$ & 21.5 & $1.29(3 \mathrm{H}, \mathrm{d}, 6.2)$ \\
\hline 16 & 118.4 & $6.36(1 \mathrm{H}, \mathrm{d}, 15.3)$ & 117.5 & $6.33(1 \mathrm{H}, \mathrm{d}, 15.5)$ \\
\hline 17 & 129.1 & $7.02(1 \mathrm{H}, \mathrm{dd}, 15.3,11.6)$ & 134.6 & $6.62(1 \mathrm{H}, \mathrm{dd}, 15.5,11.2)$ \\
\hline 18 & 125.8 & $5.97(1 \mathrm{H}, \mathrm{dd}, 11.6,11.2)$ & 129.3 & $6.24(1 \mathrm{H}, \mathrm{dd}, 14.9,11.2)$ \\
\hline 19 & 133.8 & $6.13(1 \mathrm{H}, \mathrm{dd}, 11.3,11.2)$ & 137.4 & $6.44(1 \mathrm{H}, \mathrm{dd}, 14.9,10.7)$ \\
\hline 20 & 126.9 & $6.58(1 \mathrm{H}, \mathrm{dd}, 14.5,11.3)$ & 131.7 & $6.14(1 \mathrm{H}, \mathrm{dd}, 15.0,10.7)$ \\
\hline 21 & 133.6 & $5.84(1 \mathrm{H}, \mathrm{dq}, 14.5,6.9)$ & 132.6 & $5.83(1 \mathrm{H}, \mathrm{dq}, 15.0,6.9)$ \\
\hline 22 & 18.3 & $1.79(3 \mathrm{H}, \mathrm{d}, 6.9)$ & 18.2 & $1.75(3 \mathrm{H}, \mathrm{d}, 6.9)$ \\
\hline
\end{tabular}

in vacuo to make a $30 \% \mathrm{MeOH}$ aq. solution. The obtained $30 \% \mathrm{MeOH}$ aq. solution (0.61) was applied to an ODS column $(150 \mathrm{ml}$ resin, 55 i.d. $\times 55 \mathrm{~mm}$; YMC Co., Kyoto, Japan). The column was eluted stepwise with $40 \% \mathrm{MeOH}$ aq. $(500 \mathrm{ml}), 60 \% \mathrm{MeOH}$ aq. $(500 \mathrm{ml}), 80 \% \mathrm{MeOH}$ aq. $(500 \mathrm{ml})$ and $100 \% \mathrm{MeOH}(500 \mathrm{ml})$. The $80 \% \mathrm{MeOH}$ aq. fraction including shikinefragalides was concentrated in vacuo under light-shielded condition and freeze-dried. A part (125.1 mg) of the obtained material (702.1 mg) underwent HPLC using a reverse-phase column (Capcell pak $\mathrm{C}_{18}$ MG-II, 20 i.d. $\times 250$ mm; Osaka Soda Co. Ltd., Osaka, Japan) with an isocratic solvent system of $\mathrm{CH}_{3} \mathrm{CN}-\mathrm{H}_{2} \mathrm{O}$ (40:60) at a flow rate of $7.0 \mathrm{ml} \mathrm{min}^{-1}$ detected by UV $323 \mathrm{~nm}$. The four fractions with retention times of 26-28, 30-32, 43-45, and 48-50 min were collected (Fig. S3), evaporated in vacuo, and freeze-dried under lightshielded condition to afford shikinefragalides A (1, $23.9 \mathrm{mg}), \mathrm{B}(\mathbf{2}, 14.3 \mathrm{mg}), \mathrm{C}(\mathbf{3}, 6.8 \mathrm{mg})$ and D (4, $5.9 \mathrm{mg})$, respectively.

\section{Structure elucidation of shikinefragalides A-D}

Physico-chemical properties of $\mathbf{1 - 4}$ are summarized in Table S4-1. Compounds 1-4 were expected to be analogs because they had similar physico-chemical properties (UV: $\lambda_{\max }$ 264-269 and 334-345, and ESI-MS: $\mathrm{m} / \mathrm{z}, 405$ or 421).

The structure of shikinefragalide B (2) was elucidated at first. The molecular formula of $\mathbf{2}$ was elucidated as $\mathrm{C}_{22} \mathrm{H}_{28} \mathrm{O}_{7}$ based on a $[\mathrm{M}+\mathrm{H}]^{+}$ion at $m / z, 405.1880$ (calcd. $m / z$ 405.1907) in HR-ESI-MS with 9 degrees of unsaturation. Analyses of ${ }^{1} \mathrm{H},{ }^{13} \mathrm{C}$, and HSQC spectra measured in DMSO- $d_{6}$ (Table 1, Figs. S4-2-4, 5 and 7) indicated the presence of one ester carbonyl carbon, ten $s p^{2}$ olefinic carbons, six $s p^{3}$ methine carbons including five oxygenated methines, two $s p^{3}$ methylene carbons, one oxygenated $s p^{3}$ tetrasubstituted carbon and two methyl carbons.

The ${ }^{1} \mathrm{H}-{ }^{1} \mathrm{H}$ COSY analysis of 2 revealed three partial structures I-III as shown in Fig. $2 \mathrm{a}, \mathrm{H}-14\left(\delta_{\mathrm{H}} 3.61\right) / \mathrm{H}-1\left(\delta_{\mathrm{H}}\right.$ $5.13) / \mathrm{H}-2\left(\delta_{\mathrm{H}} 5.62\right) / \mathrm{H}-3\left(\delta_{\mathrm{H}} 5.87\right) / \mathrm{H}-4\left(\delta_{\mathrm{H}} 4.00\right) / 4-\mathrm{OH}\left(\delta_{\mathrm{H}}\right.$ 
Fig. 2 Structure elucidation of shikinefragalide B (2). (a) ${ }^{1} \mathrm{H}-{ }^{1} \mathrm{H}$ COSY and key HMBC cross peaks of 2. (b) Key ROESY correlations and ${ }^{1} \mathrm{H}-{ }^{1} \mathrm{H}$ coupling constants of 2

(a)

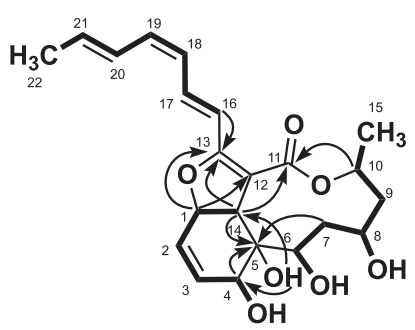

Shikinefragalide A (1) (a)

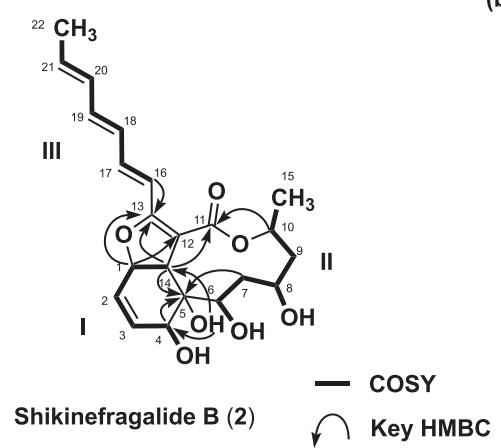

(b)

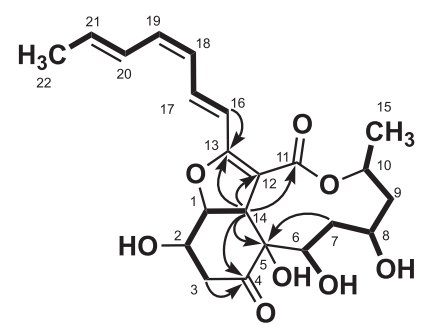

Shikinefragalide $\mathrm{C}(3)$ (b)

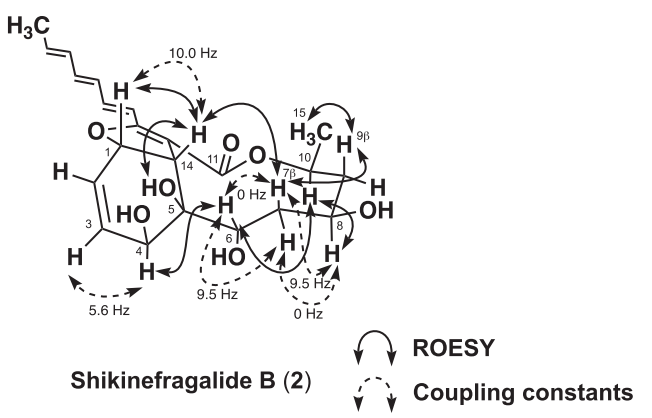

(c)

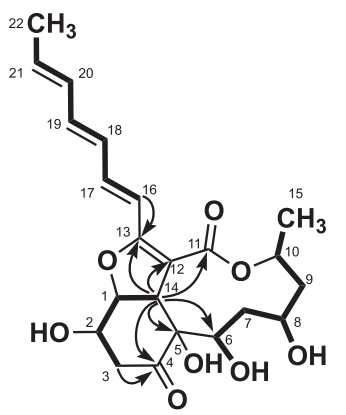

Shikinefragalide D (4)

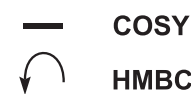

Fig. $3{ }^{1} \mathrm{H}-{ }^{1} \mathrm{H}$ COSY and key HMBC cross peaks of shikinefragalides A (1), C (3) and D (4). (a) shikinefragalide A (1), (b) shikinefragalide C (3) and shikinefragalide D (4)

$4.37)$ as I, H-6 $\left(\delta_{\mathrm{H}} 3.37\right) / \mathrm{H}_{2}-7\left(\delta_{\mathrm{H}} 1.38,2.05\right) / 6-\mathrm{OH}\left(\delta_{\mathrm{H}}\right.$ $4.08) / \mathrm{H}-8\left(\delta_{\mathrm{H}} 3.76\right) / 8-\mathrm{OH}\left(\delta_{\mathrm{H}} 4.45\right) / \mathrm{H}_{2}-9\left(\delta_{\mathrm{H}} 1.61,1.89\right) / \mathrm{H}-$ $10\left(\delta_{\mathrm{H}} 4.53\right) / \mathrm{H}_{3}-15\left(\delta_{\mathrm{H}} 1.29\right)$ as II, and H-16 $\left(\delta_{\mathrm{H}} 6.33\right) / \mathrm{H}-17$ $\left(\delta_{\mathrm{H}} 6.62\right) / \mathrm{H}-18\left(\delta_{\mathrm{H}} 6.24\right) / \mathrm{H}-19\left(\delta_{\mathrm{H}} 6.44\right) / \mathrm{H}-20\left(\delta_{\mathrm{H}} 6.14\right) / \mathrm{H}-$ $21\left(\delta_{\mathrm{H}} 5.83\right) / \mathrm{H}_{3}-22\left(\delta_{\mathrm{H}} 1.75\right)$ as III. The geometry of three double bonds in III was determined to be all $E$ by large ${ }^{1} \mathrm{H}$ ${ }^{1} \mathrm{H}$ coupling constants $(15.5,14.9$ and $15.0 \mathrm{~Hz})$. Based on $\mathrm{HMBC}$ cross peaks from $\mathrm{H}-1$ to $\mathrm{C}-13\left(\delta_{\mathrm{C}} 158.0\right)$ and $\mathrm{C}-12$ $\left(\delta_{\mathrm{C}} 107.8\right)$, from $\mathrm{H}-14$ to $\mathrm{C}-13$ and $\mathrm{C}-5\left(\delta_{\mathrm{C}} 75.4\right)$, from $5-\mathrm{OH}\left(\delta_{\mathrm{H}} 4.10\right)$ to $\mathrm{C}-14\left(\delta_{\mathrm{C}} 46.6\right)$ and $\mathrm{C}-4\left(\delta_{\mathrm{C}} 64.5\right)$, from $\mathrm{H}-4$ to $\mathrm{C}-5$, and from H-16 to C-13, it was suggested 2 has a dihydrofuran-fused cyclohex-2-enol ring moiety including I, which is connected to a $1,3,5$-heptatrienyl moiety III at C-13 position. Finally, the correlations in $\mathrm{HMBC}$ from $\mathrm{H}_{2}-7$ to $\mathrm{C}-5$, from $\mathrm{H}-10$ to $\mathrm{C}-11\left(\delta_{\mathrm{C}} 165.2\right)$, and from $\mathrm{H}-14$ to $\mathrm{C}-$ 11 , suggested the presence of a 10 -membered macrolactone ring including II, which was connected at C-12 and C-5 positions of a dihydrofuran-fused cyclohexene ring moiety. From all results described above, 2 was elucidated as a new analog of colletofragarones [13], and designated shikinefragalide B (Fig. 1).

The relative configuration of $\mathbf{2}$ was established by ROESY and ${ }^{1} \mathrm{H}^{-1} \mathrm{H}$ coupling constant analyses (Fig. 2b). Key ROESY correlations between H-1/H-14, H-14/5-OH, H-4/H-6, H-6/H-10, H-8/H-10, $\mathrm{H}_{\beta}-9 / \mathrm{H}_{\beta}-7, \mathrm{H}_{\beta}-9 / \mathrm{H}_{3}-15$ and
$\mathrm{H}_{\beta}-7 / \mathrm{H}-14$ and coupling constants between $1 / 14(10.0 \mathrm{~Hz})$, $3 / 4(5.6 \mathrm{~Hz}), 6 / 7 \beta(0 \mathrm{~Hz}), 6 / 7 \alpha(9.5 \mathrm{~Hz}), 7 \beta / 8(9.5 \mathrm{~Hz})$ and $7 \alpha / 8(0 \mathrm{~Hz})$ suggested the relative configuration of 2 to be $1 S^{*}, 4 S^{*}, 5 S^{*}, 6 R^{*}, 8 S^{*}, 10 S^{*}, 14 S^{*}$. The absolute configuration of 2 was elucidated by circular dichroism (CD) spectra. Compared with reported CD spectrum of colletofragarone A2 [14], 2 had same positive cotton effect around $240 \mathrm{~nm}$ (Fig. S4-2-16), the absolute configuration of 2 should be $1 S, 4 S, 5 S, 6 R, 8 S, 10 S, 14 S$.

The molecular formula of shikinefragalide A (1) was determined to be $\mathrm{C}_{22} \mathrm{H}_{28} \mathrm{O}_{7}$, which was same to that of $\mathbf{2}$, based on a $[\mathrm{M}+\mathrm{H}]^{+}$ion at $\mathrm{m} / \mathrm{z} 405.1866$ (calcd. $\mathrm{m} / \mathrm{z}$ 405.1907) in HR-ESI-MS. ${ }^{1} \mathrm{H},{ }^{13} \mathrm{C}$, and HMQC spectra of $\mathbf{1}$ measured in DMSO- $d_{6}$ (Table 1, Figs. S4-1-4, 5 and 7), resembled those of $\mathbf{2}$, except for the proton and carbon signals of a 1,3,5-heptatrienyl moiety. The interpretation of ${ }^{1} \mathrm{H}-{ }^{1} \mathrm{H}$ COSY and HMBC of $\mathbf{1}$ suggested $\mathbf{1}$ has a same planar structure to 2 . (Fig. 3a). The difference was found in geometry of three double bonds, which was determined to be $16 E, 18 Z$ and $20 E$ by ${ }^{1} \mathrm{H}-{ }^{1} \mathrm{H}$ coupling constants between $16 / 17(15.3 \mathrm{~Hz}), 18 / 19(11.2 \mathrm{~Hz})$, and 20/21 (14.5 Hz), respectively. The relative configuration of $\mathbf{1}$ was established by ROESY and ${ }^{1} \mathrm{H}-{ }^{1} \mathrm{H}$ coupling constant analyses (Fig. 4a) same as $\mathbf{2}$. The absolute configuration of $\mathbf{1}$ was also elucidated to be $1 S, 4 S, 5 S, 6 R, 8 S, 10 S, 14 S$ by CD spectrum 
Fig. 4 Key ROESY correlations and ${ }^{1} \mathrm{H}-{ }^{1} \mathrm{H}$ coupling constants of shikinefragalides A (1), C (3) and D (4). (a) shikinefragalide A (1), (b) shikinefragalide C (3) and shikinefragalide D (4) (a)

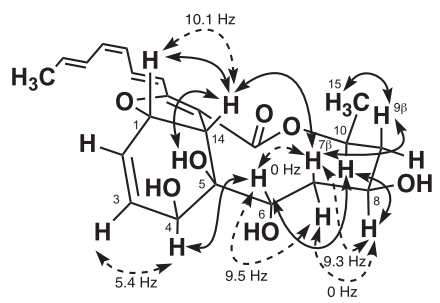

Shikinefragalide A (1) (b)

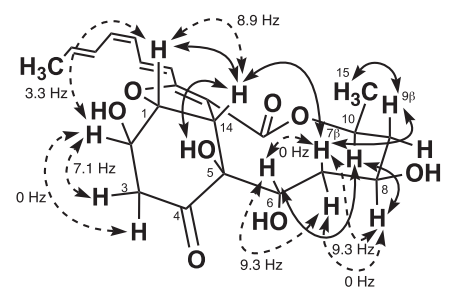

Shikinefragalide C (3) (c)
(Fig. S4-1-16). From these observations described above, 1 was elucidated as a new analog, which was a $18 Z$ isomer of 2 and designated shikinefragalide A (Fig. 1).

The molecular formula of shikinefragalide $\mathrm{C}$ (3) was determined to be $\mathrm{C}_{22} \mathrm{H}_{28} \mathrm{O}_{8}$, based on a $[\mathrm{M}+\mathrm{H}]^{+}$ion at $\mathrm{m} / z$ 421.1839 (calcd. $\mathrm{m} / \mathrm{z}$ 421.1856) in HR-ESI-MS with 9 degrees of unsaturation, indicating the presence of an additional oxygen atom compared with that of $1 .{ }^{1} \mathrm{H},{ }^{13} \mathrm{C}$, and HSQC spectra of $\mathbf{3}$ measured in DMSO- $d_{6}$ (Table 2, Fig. S4-3-4, 5 and 7), resembled those of 1, except for the proton and carbon signals of a partial structure $\mathbf{I}$. The interpretation of ${ }^{1} \mathrm{H}^{1}{ }^{1} \mathrm{H}$ COSY and HMBC of $\mathbf{3}$ (Fig. 3b), suggested the $\mathbf{3}$ has a 3-hydroxylcyclohexan-1-one ring moiety, instead of a cyclohex-2-enol ring moiety of $\mathbf{1}$.

The relative configuration of $\mathbf{3}$ was established by ROESY and ${ }^{1} \mathrm{H}-{ }^{1} \mathrm{H}$ coupling constant analyses (Fig. 4b). Key ROESY correlations between $\mathrm{H}-1 / \mathrm{H}-14, \mathrm{H}-14 / 5-\mathrm{OH}$, H-6/H-10, H-8/H-10, $\mathrm{H}_{\beta}-9 / \mathrm{H}_{\beta}-7, \mathrm{H}_{\beta}-9 / \mathrm{H}_{3}-15$ and $\mathrm{H}_{\beta}-7 / \mathrm{H}-14$ and coupling constants between $1 / 14(8.9 \mathrm{~Hz}), 1 / 2(3.3 \mathrm{~Hz})$, $2 / 3 \alpha(7.1 \mathrm{~Hz}), 2 / 3 \beta(0 \mathrm{~Hz}), 6 / 7 \beta(0 \mathrm{~Hz}), 6 / 7 \alpha(9.3 \mathrm{~Hz}), 7 \beta / 8$ $(9.3 \mathrm{~Hz})$ and $7 \alpha / 8(0 \mathrm{~Hz})$ suggested the relative configuration of 3 to be $1 R^{*}, 2 R^{*}, 5 S^{*}, 6 R^{*}, 8 S^{*}, 10 S^{*}, 14 S^{*}$. The absolute configuration of $\mathbf{3}$ was also elucidated by the comparison with reported CD spectrum of colletoin B [14] to be $1 R, 2 R, 5 S, 6 R, 8 S, 10 S, 14 S$ (Fig. S4-3-10). From all results described above, $\mathbf{3}$ was elucidated as a new analog, and designated shikinefragalide C (Fig. 1).
The molecular formula of shikinefragalide $\mathrm{D}$ (4) was determined to be $\mathrm{C}_{22} \mathrm{H}_{28} \mathrm{O}_{8}$, which was same to that of $\mathbf{3}$, based on a $[\mathrm{M}+\mathrm{H}]^{+}$ion at $\mathrm{m} / \mathrm{z} 421.1845$ (calcd. $\mathrm{m} / \mathrm{z}$ 421.1856) in HR-ESI-MS. ${ }^{1} \mathrm{H},{ }^{13} \mathrm{C}$, and HMQC spectra of 4 measured in DMSO- $d_{6}$ (Table 2, Figs. S4-4-4, 5 and 7), resembled those of $\mathbf{3}$, except for the proton and carbon signals of a 1,3,5-heptatrienyl moiety. The interpretation of ${ }^{1} \mathrm{H}-{ }^{1} \mathrm{H}$ COSY and HMBC of $\mathbf{4}$ suggested $\mathbf{4}$ has a same planar structure to 3. (Fig. 3c). The difference was observed in geometry of three double bonds, which was determined to be all $E$ by large ${ }^{1} \mathrm{H}-{ }^{1} \mathrm{H}$ coupling constants between $16 / 17$ $(15.3 \mathrm{~Hz}), 18 / 19(15.0 \mathrm{~Hz})$, and $20 / 21(15.1 \mathrm{~Hz})$, respectively. The relative configuration of $\mathbf{4}$ was established by ROESY and ${ }^{1} \mathrm{H}-{ }^{1} \mathrm{H}$ coupling constant analyses (Fig. 4c) same as 3. The absolute configuration of $\mathbf{4}$ was also elucidated to be $1 R, 2 R, 5 S, 6 R, 8 S, 10 S, 14 S$ by $C D$ spectrum (Fig. S4-4-10). From these results described above, 4 was elucidated as a new analog, which was a $18 E$ isomer of $\mathbf{3}$ and designated shikinefragalide D (Fig. 1).

\section{Biological activity}

Compounds 1 and 2, isolated with over $10 \mathrm{mg}$, were tested for in vitro antimalarial activity against both a chloroquinesensitive FCR3 strain and a chloroquine-resistant K1 strain of $P$. falciparum, as well as for cytotoxicity in human MRC5 cells (Table 3, Fig S6). Compound 1 displayed in vitro 
Table $2{ }^{1} \mathrm{H}$ and ${ }^{13} \mathrm{C}$ NMR data of $\mathbf{3}$ and $\mathbf{4}$ measured in DMSO- $d_{6}$

\begin{tabular}{|c|c|c|c|c|}
\hline \multirow[b]{2}{*}{ position } & \multicolumn{2}{|c|}{ Shikinefragalide C (3) } & \multicolumn{2}{|c|}{ Sihikinefragalide D (4) } \\
\hline & $\delta_{\mathrm{C}}$ & $\begin{array}{l}\delta_{\mathrm{H}} \text { (int., mult., } \\
J \text { in } \mathrm{Hz} \text { ) }\end{array}$ & $\delta_{\mathrm{C}}$ & $\begin{array}{l}\delta_{\mathrm{H}} \text { (int., mult., } \\
J \text { in } \mathrm{Hz} \text { ) }\end{array}$ \\
\hline 1 & 83.4 & $\begin{array}{l}4.84(1 \mathrm{H}, \mathrm{dd}, \\
8.9,3.3)\end{array}$ & 83.8 & $\begin{array}{l}4.81(1 \mathrm{H}, \mathrm{dd}, \\
8.9,3.4)\end{array}$ \\
\hline 2 & 67.9 & $4.39(1 \mathrm{H}$, br. s) & 67.9 & $4.34(1 \mathrm{H}$, br. $\mathrm{d}, 7.1)$ \\
\hline $2-\mathrm{OH}$ & & $4.08(1 \mathrm{H}$, br. $\mathrm{d})$ & & Not observed \\
\hline $3 \alpha$ & 44.8 & $\begin{array}{l}2.70(1 \mathrm{H}, \mathrm{dd}, \\
17.3,7.1)\end{array}$ & 44.8 & $2.64(\mathrm{dd}, 17.3,7.1)$ \\
\hline $3 \beta$ & & $2.90(1 \mathrm{H}, \mathrm{d}, 17.3)$ & & $2.88(\mathrm{~d}, 17.3)$ \\
\hline 4 & 210.9 & - & 210.8 & - \\
\hline 5 & 82.1 & - & 82.1 & - \\
\hline $5-\mathrm{OH}$ & & $4.14(1 \mathrm{H}$, br. s) & & Not observed \\
\hline 6 & 68.7 & $\begin{array}{l}3.28(1 \mathrm{H}, \mathrm{dd}, \\
9.3,4.0)\end{array}$ & 68.7 & $3.26(1 \mathrm{H}, \mathrm{d}, 8.9)$ \\
\hline $6-\mathrm{OH}$ & & $4.25(1 \mathrm{H}$, br. $\mathrm{d} 4.0)$ & & Not observed \\
\hline $7 \alpha$ & 41.9 & $\begin{array}{l}1.49(1 \mathrm{H}, \mathrm{dd}, \\
13.9,9.3)\end{array}$ & 41.9 & $\begin{array}{l}1.46(1 \mathrm{H}, \mathrm{dd}, \\
14.2,8.9)\end{array}$ \\
\hline $7 \beta$ & & $\begin{array}{l}2.09(1 \mathrm{H}, \mathrm{dd}, \\
13.9,9.3)\end{array}$ & & $\begin{array}{l}2.09(1 \mathrm{H}, \mathrm{dd}, \\
14.2,9.5)\end{array}$ \\
\hline 8 & 68.3 & $3.72(1 \mathrm{H}, \mathrm{m})$ & 68.2 & $3.70(1 \mathrm{H}, \mathrm{m})$ \\
\hline $8-\mathrm{OH}$ & & $4.55(1 \mathrm{H}$, br. s) & & Not observed \\
\hline $9 \alpha$ & 42.3 & $\begin{array}{l}1.89(1 \mathrm{H}, \mathrm{br} . \\
\mathrm{d}, 14.6)\end{array}$ & 41.9 & $1.87(1 \mathrm{H}$, br. $\mathrm{d}, 14.4)$ \\
\hline $9 \beta$ & & $\begin{array}{l}1.63(1 \mathrm{H}, \mathrm{ddd}, 14.6, \\
8.0,8.0)\end{array}$ & & $\begin{array}{l}1.61(1 \mathrm{H}, \mathrm{ddd}, 14.4 \text {, } \\
8.0,8.0)\end{array}$ \\
\hline 10 & 70.2 & $4.80(1 \mathrm{H}, \mathrm{m})$ & 70.1 & $4.78(1 \mathrm{H}, \mathrm{m})$ \\
\hline 11 & 163.8 & - & 163.8 & - \\
\hline 12 & 103.5 & - & 102.8 & - \\
\hline 13 & 163.8 & - & 163.9 & - \\
\hline 14 & 52.8 & $3.80(1 \mathrm{H}, \mathrm{d}, 8.9)$ & 52.7 & $3.77(1 \mathrm{H}, \mathrm{d}, 8.9)$ \\
\hline 15 & 20.9 & $1.29(3 \mathrm{H}, \mathrm{d}, 6.4)$ & 20.9 & $1.28(3 \mathrm{H}, \mathrm{d}, 6.4)$ \\
\hline 16 & 117.7 & $6.77(1 \mathrm{H}, \mathrm{d}, 15.3)$ & 116.7 & $6.74(1 \mathrm{H}, 15.3)$ \\
\hline 17 & 133.1 & $\begin{array}{l}7.18(1 \mathrm{H}, \mathrm{dd}, \\
15.3,11.6)\end{array}$ & 138.6 & $\begin{array}{l}6.75(1 \mathrm{H}, \mathrm{dd}, \\
15.3,9.0)\end{array}$ \\
\hline 18 & 125.6 & $\begin{array}{l}6.02(1 \mathrm{H}, \mathrm{dd}, \\
11.6,11.1)\end{array}$ & 129.1 & $\begin{array}{l}6.29(1 \mathrm{H}, \mathrm{dd}, \\
15.0,9.9)\end{array}$ \\
\hline 19 & 136.0 & $\begin{array}{l}6.24(1 \mathrm{H}, \mathrm{dd}, \\
11.4,11.1)\end{array}$ & 139.8 & $\begin{array}{l}6.54(1 \mathrm{H}, \mathrm{dd}, \\
15.0,10.8)\end{array}$ \\
\hline 20 & 127.0 & $\begin{array}{l}6.63(1 \mathrm{H}, \mathrm{dd}, \\
15.1,11.4)\end{array}$ & 131.7 & $\begin{array}{l}6.20(1 \mathrm{H}, \mathrm{dd}, \\
15.1,10.8)\end{array}$ \\
\hline 21 & 135.0 & $\begin{array}{l}5.93(1 \mathrm{H}, \mathrm{dq}, \\
15.1,6.8)\end{array}$ & 134.3 & $\begin{array}{l}5.90(1 \mathrm{H}, \mathrm{dq}, \\
15.1,6.9)\end{array}$ \\
\hline 22 & 18.4 & $1.79(3 \mathrm{H}, \mathrm{d}, 6.8)$ & 18.4 & $1.76(3 \mathrm{H}, \mathrm{d}, 6.9)$ \\
\hline
\end{tabular}

weak antimalarial activity against both a chloroquinesensitive $P$. falciparum FCR3 strain and a chloroquineresistant $P$. falciparum $\mathrm{K} 1$ strain with $\mathrm{IC}_{50}$ values of 62.7 and $186.6 \mu \mathrm{M}$, respectively. Compound 2 showed weaker antimalarial activity with $\mathrm{IC}_{50}$ values of 104.5 and $209.4 \mu \mathrm{M}$ than 1. In addition, $\mathbf{1}$ and $\mathbf{2}$ showed weak cytotoxicity against human MRC-5 cells, with $\mathrm{IC}_{50}$ values of 48.2 and $76.3 \mu \mathrm{M}$, respectively, indicating selectivity indices $\left(\mathrm{IC}_{50}\right.$ values against $\mathrm{MRC}-5$ cells/ $\mathrm{IC}_{50}$ values against $P$. falciparum strains) ranging from 0.3 to 0.8 .

Compounds $\mathbf{1 - 4}$ demonstrated no antimicrobial activity against B. subtilis, K. rhizophila, E. coli, X. oryzae, C. albicans and $M$. racemosus at $10 \mu \mathrm{g}$ on a paper disc method.

\section{Discussion}

In this study, four new fungal macrolides, named shikinefragalides A (1)-D (4), were discovered from a static cultured material of a Stachybotryceae sp. FKI-9632 by PC screening. To data, there have been several analogs reported such as colletofragarones [13], colletoins [14], and dictyosphaeric acids [15] (Fig. S5). To our best knowledge, the biosynthetic pathway of colletofragarone-related compounds has not been clarified yet. The main differences among colletofragarone-related compounds and 1-4 are degrees of oxidation at C-2, C-3, C-4, C-5, C-6, and C-8 positions, the decipher and comparison of their biosynthetic pathway would reveal responding enzymes for oxidation.

Colletofragarone A2 and colletoin A were reported to show cytotoxicity against Saos-2 (p53R175H) cells, with $\mathrm{IC}_{50}$ values of 0.35 and $0.36 \mu \mathrm{M}$, respectively, whereas colletoins $\mathrm{B}$ and $\mathrm{C}$ were less active, with $\mathrm{IC}_{50}$ values of 21 and $12 \mu \mathrm{M}$, respectively [14]. Dictyosphaeric acid A was reported to have antibacterial activity against methicillinresistant Staphylococcus aureus (MRSA), vancomycinresistant Enterococci, and $C$. albicans, while dictyosphaeric acid B was reported to show no significant antibacterial activity $[15,16]$. These reports suggest that an $\alpha$, $\beta$-unsaturated carbonyl group in their six-membered ring is essential for their activity (Fig. S5) [14, 16]. Compounds 14 without an $\alpha, \beta$-unsaturated carbonyl group, showed no antibacterial activity, which also support its importance.

This is the first report of antimalarial activity of colletofragarone-related compounds against $P$. falciparum. Compounds $\mathbf{1}$ and $\mathbf{2}$ showed weak in vitro antimalarial activity. Recently, dictyosphaeric acid A was passed in silico screening against COVID-19 and was reported to be a potential inhibitor of the host enzyme, transmembrane protease serine 2 (TMPRSS2) [17]. Since 1-4 are sensitive to light and gradually degraded even under light-shielded condition, they are not suitable for long-term storage, and it would be difficult to evaluate their activity against various targets. Therefore, it is necessary to chemically modify colletofragarone-related compounds including 1-4 to improve their stability for pharmaceutical applications by inducing them.

In this study, we used 25 unidentified fungi having less than $90 \%$ homology with known species for sources of PC screening. As a result, we could select 4 producers of 
Table 3 In vitro antimalarial activity, cytotoxicity, and selectivity index of $\mathbf{1 , 2}$ and chloroquine (an antimalarial drug)

\begin{tabular}{|c|c|c|c|c|c|}
\hline \multirow{3}{*}{ Compound } & \multicolumn{5}{|l|}{$\mathrm{IC}_{50}[\mu \mathrm{M}]$} \\
\hline & \multicolumn{2}{|c|}{ Antimalarial activity } & \multirow{2}{*}{$\begin{array}{l}\text { Cytotoxicity } \\
\text { (MRC-5) }\end{array}$} & \multicolumn{2}{|c|}{ Selectivity index (SI) } \\
\hline & K1 strain* & FCR3 strain** & & MRC-5/K1 & MRC-5/FCR3 \\
\hline Shikinefragalide A (1) & 186.6 & 62.7 & 48.2 & 0.3 & 0.8 \\
\hline Shikinefragalide B (2) & 209.4 & 104.5 & 76.3 & 0.4 & 0.7 \\
\hline Chloroquine ${ }^{* * *}$ & 0.577 & 0.047 & 58.2 & 101 & 1,238 \\
\hline
\end{tabular}

*chloroquine-resistant strain

**chloroquine-sensitive strain

***drug commonly used to treat malaria presumed new compounds with higher rate of $16 \%$ than those of identified species (less than 5\%) in our research team, suggesting that fungal strains with high novelty are very good sources for PC screening to improve efficacy of discovery new fungal secondary metabolites.

Acknowledgements We are grateful to Distinguished Emeritus Professor Satoshi Ōmura (Kitasato University) for his helpful support and valuable guidance and suggestions. We thank Dr. K. Nagai and Ms. N. Sato (School of Pharmacy, Kitasato University) for various instrumental analyses, and Mr. T. Tokiwa for taking fungal photo and support on paper disc evaluation. This study was also partially supported by the Platform Project for Supporting Drug Discovery and Life Science Research (Basis for Supporting Innovative Drug Discovery and Life Science Research (BINDS)) from the Japan Agency for Medical Research \& Development (AMED) under Grant Numbers JP19am0101096.

\section{Compliance with ethical standards}

Conflict of interest The authors declare no competing interests.

Publisher's note Springer Nature remains neutral with regard to jurisdictional claims in published maps and institutional affiliations.

\section{References}

1. Newman DJ, Cragg GM. Natural products as sources of new drugs over the nearly four decades from $01 / 1981$ to $09 / 2019$. J Nat Prod. 2020;83:770-803.

2. Kandasamy R, London D, Stam L, von Deyn W, Zhao X, Salgado VL, et al. Afidopyropen: new and potent modulator of insect transient receptor potential channels. Insect Biochem Mol. 2017;84:32-9.

3. Meng X, Fang Y, Ding M, Zhang Y, Jia K, Li Z, et al. Developing fungal heterologous expression platforms to explore and improve the production of natural products from fungal biodiversity. Biotechnol Adv. 2021;54:107866.

4. Keller NP. Fungal secondary metabolism: regulation, function, and drug discovery. Nat Rev Microbiol. 2019;17:167-80.

5. Matsuo H, Hokari R, Ishiyama A, Iwatsuki M, Higo M, Nonaka $\mathrm{K}$, et al. Hatsusamides A and B: two new metabolites produced by the deep-sea-derived fungal strain Penicillium steckii FKJ-0213. Mar Drugs. 2020;18:513.

6. Miyano R, Matsuo H, Nonaka K, Mokudai T, Niwano Y, Shiomi $\mathrm{K}$, et al. Pochoniolides $\mathrm{A}$ and $\mathrm{B}$, new antioxidants from the fungal strain Pochonia chlamydosporia var. spinulospora FKI-7537. J Biosci Bioeng. 2018;126:661-6.

7. Matsuo H, Mokudai T, Higo M, Nonaka K, Nagano Y, Hagahama $\mathrm{T}$, et al. Cipralphelin, a new anti-oxidative $N$-cinnamoyl tripeptide produced by the deep sea-derived fungal strain Penicillium brevicompactum FKJ-0123. J Antibiot. 2019;72:775-8.

8. Dictionary of Natural Products, on DVD (Ver. 26.2) CRC Press 2021.

9. Otoguro K, Kohana A, Manabe C, Ishiyama A, Ui H, Shiomi K, et al. Potent antimalarial activities of polyether antibiotic, X-206. J Antibiot. 2001;54:658-63.

10. Otoguro K, Ui H, Ishiyama A, Arai N, Kobayashi M, Takahashi $\mathrm{Y}$, et al. In vitro antimalarial activities of the microbial metabolites. J Antibiot. 2003;56:322-4.

11. Altschul SF, Madden TL, Schaffer AA, Zhang J, Zhang Z, Miller W, et al. Gapped BLAST and PSI-BLAST: a new generation of protein database search programs. Nucleic Acids Res. 1997;25:3389-402.

12. Crous PW, Schumacher RK, Wingfield MJ, Akulov A, Denman S, Roux J, et al. New and interesting fungi. 1. Fungal Syst Evol. 2018;1:169-216.

13. Inoue $M$, Takenaka $H$, Tsurushima $T$, Miyagawa $H$, Ueno $T$. Colletofragarones $\mathrm{A} 1$ and $\mathrm{A} 2$, novel germination self-inhibitors from the Fungus Colletotrichum fragariae. Tetrahedron Lett. 1996;37:5731-4.

14. Sadahiro Y, Hitora Y, Tsukamoto S. Colletofragarone A2 and colletoins A-C from a fungus Colletotrichum sp. decrease mutant p53 levels in cells. J Nat Prod. 2021;84:3131-7.

15. Bugni TS, Janso JE, Williamson RT, Feng X, Bernan VS, Greenstein M, et al. Dictyosphaeric acids A and B: new decalactones from an Undescribed Penicillium sp. obtained from the alga Dictyosphaeria versluyii. J Nat Prod. 2004;67:1396-9.

16. Burns AR, McAllister GD, Shanahan SE, Taylor RJK. Total synthesis and structural reassignment of $(+)$-dictyosphaeric acid A: A tandem intramolecular michael addition/alkene migration approach. Angew Chem Int Ed. 2010;49:5574-7.

17. Rahman N, Basharat Z, Yousuf M, Castaldo G, Rastrelli L, Khan $\mathrm{H}$. Virtual screening of natural products against type II transmembrane serine protease (TMPRSS2), the priming agent of Coronavirus 2 (SARS-CoV-2). Molecules 2020;25:2271. 